\title{
Pengaruh Pelatihan Terhadap Kompetensi Karyawan pada PT. Baja Panelindo Utama di Jakarta
}

\author{
Haerofiatna \\ Universitas Primagraha, Serang, Banten, Indonesia \\ Email: haerofiatna@primagraha.ac.id
}

\begin{abstract}
This study aims to determine the effect of training on employee competence at PT. Steel Panelindo Utama in Jakarta. The method used is explanatory research with a sample of 65 respondents. The analysis technique uses statistical analysis with regression, correlation, determination and hypothesis testing. The results of this study of the training variable obtained an average score of 3.805 with good criteria. The employee competency variable obtained an average score of 3.892 with good criteria. Training has a positive and significant effect on employee competence with a regression equation value of $Y=13.040+0.680 X$, and a correlation coefficient value of 0.806 or has a strong relationship with a determination value of $65.0 \%$. Hypothesis testing obtained a significance of $0.000<0.05$.
\end{abstract}

Keywords: Training, Employee Competence.

\begin{abstract}
Abstrak
Penelitian ini bertujuan untuk mengetahui pengaruh pelatihan terhadap kompetensi karyawan pada PT. Baja Panelindo Utama di Jakarta. Metode yang digunakan adalah explanatory research dengan sampel sebanyak 65 responden. Teknik analisis menggunakan analisis statistik dengan pengujian regresi, korelasi, determinasi dan uji hipotesis. Hasil penelitian ini variabel pelatihan diperoleh nilai rata-rata skor sebesar 3,805 dengan kriteria baik. Variabel kompetensi karyawan diperoleh nilai rata-rata skor sebesar 3,892 dengan kriteria baik. Pelatihan berpengaruh positif dan signifikan terhadap kompetensi karyawan dengan nilai persamaan regresi $\mathrm{Y}=13,040+0,680 \mathrm{X}$, dan nilai koefisien korelasi 0,806 atau memiliki tingkat hubungan yang kuat dengan nilai determinasi $65,0 \%$. Uji hipotesis diperoleh signifikansi $0,000<0,05$.
\end{abstract}

Kata Kunci: Pelatihan, Kompetensi Karyawan.

\section{PENDAHULUAN}

Sumber daya manusia pada perusahaan perlu dikelola secara profesional agar terwujud suatu keseimbangan antara kebutuhan karyawan dengan tuntutan dan kemampuan organsiasi perusahaan. Manusia sebagai faktor tenaga kerja dapat tumbuh dan berkembang dengan baik, bersemangat dalam melakukan aktivitas kerja, maka sangat penting memberi perhatian terhadap keadaan pegawai. Dalam era globalisasi yang semakin maju terbentuk persaingan yang semakin tajam, dimana setiap perusahaan dan para pelaku ekonomi hendaknya mampu menyesuaikan diri dengan perubahan yang terjadi, serta memanfaatkan peluang dan tantangan yang muncul. Untuk mencapai tujuan 
perusahaan diperlukan kemampuan perusahaan dalam memanfaatkan sumber-sumber yang ada, sehingga mempunyai tingkat hasil dan daya guna yang tinggi.

Karyawan merupakan aset untuk menjamin kelancaran penyelenggaraan perusahaan oleh karena itu diperlukan karyawan yang terampil, cekatan dan mempunyai kemampuan yang memadai dalam melaksanakan pekerjaannya. Pengelolaan sumber daya manusia, salah satunya adalah melalui pelatihan yang diberikan kepada karyawan dapat mendorong para karyawan bekerja lebih giat, hal ini disebabkan karena karyawan akan berusaha mencapai prestasi kerja yang lebih tinggi. Perusahaan juga tidak akan segan- segan mengeluarkan sejumlah uang untuk keperluan pelatihan karyawan walaupun terkadang jumlah yang dikeluarkan cukup besar, sebab hal ini dianggap perusahaan sebagai suatu investasi dalam sumber daya manusia dan diharapkan dapat meningkatkan kinerja karyawan. Melalui proses pelatihan tersebut, kompetensi karyawan dapat ditingkatkan demi tercapainya standarisasi kompetensi yang dibutuhkan perusahaan untuk mencapai target yang telah dicanangkan.

Pelatihan bagi karyawan sangat penting untuk diterapkan dalam suatu perusahaan. Dengan adanya pelatihan diharapkan karyawan akan dapat bekerja secara lebih efektif dan efisien terutama untuk menghadapi perubahan-perubahan yang terjadi seperti perubahan teknologi, perubahan metode kerja, menuntut pula perubahan sikap, tingkah laku, ketrampilan dan pengetahuan.

Kkinerja merupakan prestasi kerja atau prestasi sesungguhnya yang dicapai oleh seorang karyawan. Simanjuntak (2005:9) berpendapat bahwa yang dimaksud dengan kinerja adalah melaksanakan tugasnya sesuai dengan tanggung jawab yang diberikan kepadanya. Selanjutnya dalam Mangkunegara (2007:9) mendefinisikan kinerja sebagai perbandingan hasil yang dicapai dengan tenaga kerja per satuan waktu (lazimnya per jam).

Penilaian kinerja dapat bersifat subyektif atau obyektif. Obyektif berarti penilaian kinerja dapat juga diterima, diukur oleh pihak lain selain yang melakukan penilaian dan bersifat kuantitatif. Sedangkan penilaian yang bersifat subyektif berarti penilaian yang berdasarkan pendapat pribadi atau standar pribadi orang yang melakukan penilaian dan sulit untuk diterima oleh orang lain

\section{TINJAUAN PUSTAKA}

\section{Pelatihan}

Menurut Dessler (2013) Pelatihan (training) merupakan suatu usaha peningkatan pengetahuan dan keahlian seorang pegawai untuk mengerjakan suatu pekerjaan tertentu, dengan adanya peningkatan keahlian, pengetahuan, wawasan, dan sikap pegawai pada tugas- tugasnya melalui program pelatihan yang sudah dilaksanakan dalam organisasi dapat ditingkatkan

\section{Kompetensi Karyawan}

Kompetensi dalam penelitian ini mengacu pada teori David c. Clelland dalam Rivai (2020:102), yaitu sesuatu yang orang bawa bagi suatu pekerjaan dalam bentuk dan tingkatan perilaku yang berbeda. Kompetensi memeengaruhi aspek proses dari kinerja pekerjaan.

\section{METODE PENELITIAN}

\section{Populasi}

Yang dijadikan sebagai populasi dalam penelitian ini adalah responden yang berjumlah 65 responden PT. Baja Panelindo Utama di Jakarta

\section{Sampel}


Teknik pengambilan sampling dalam penelitian ini adalah sampel jenuh, dimana semua anggota populasi dijadikan sebagai sampel. Dengan demikian sampel dalam penelitian ini sampel yang digunakan berjumlah 65 responden.

\section{Jenis Penelitian}

Jenis penelitian yang dipakai adalah asosiatif, dimana tujuannya adalah untuk mengetahui atau mencari keterhubungan antara variabel independen terhadap variabel dependennya

\section{Metode Analisis Data}

Dalam menganalisis data digunakan uji validitas, uji reliabilitas, analisis regresi linier sederhana, analisis koefisien korelasi, analisis koefisien determinasi dan pengujian hipotesis.

\section{HASIL PENELITIAN}

\section{Analisis Deskriptif}

Pada pengujian ini digunakan untuk mengetahui skor minimum dan maksimum skor tertinggi, ratting score dan standar deviasi dari masing-masing variabel. Adapun hasilnya sebagai berikut:

Tabel 1. Hasil Analisis Descriptive Statistics

\section{Descriptive Statistics}

\begin{tabular}{lr|r|r|r|r} 
& N & Minimum & $\begin{array}{c}\text { Maximu } \\
\mathrm{m}\end{array}$ & Mean & Std. Deviation \\
\hline Pelatihan (X) & 65 & 28 & 49 & 38.05 & 4.625 \\
\hline $\begin{array}{l}\text { Kompetensi Karyawan } \\
(Y)\end{array}$ & 65 & 30 & 50 & 38.92 & 3.902 \\
\hline Valid N (listwise) & 65 & & & & \\
\hline
\end{tabular}

Pelatihan diperoleh varians minimum sebesar 28 dan varians maximum 49 dengan ratting score sebesar 3,805 dengan standar deviasi 4,625. Skor ini termasuk pada rentang sakala 3,40 - 4,19 dengan kriteria baik atau setuju. Kompetensi karyawan diperoleh varians minimum sebesar 30 dan varians maximum 50 dengan ratting score sebesar 3,892 dengan standar deviasi 3,902. Skor ini termasuk pada rentang sakala 3,40 - 4,19 dengan kriteria baik atau setuju.

2. Analisis Kuantitatif.

Pada analisis ini dimaksudkan untuk mengetahui pengaruh variabel independen terhadap variabel dependen. Adapun hasil pengujian sebagai berikut:

\section{a. Analisis Regresi Linier Sederhana}

Uji regresi ini dimaksudkan untuk mengetahui perubahan variabel dependen jika variabel independen mengalami perubahan. Adapun hasil pengujiannya sebagai berikut:

Tabel 2. Hasil Pengujian Regresi Linier Sederhana

\section{Coefficients $^{\mathbf{a}}$}




\begin{tabular}{lr|r|r|r|r} 
& $\begin{array}{c}\text { Unstandardized } \\
\text { Coefficients }\end{array}$ & $\begin{array}{l}\text { Standardized } \\
\text { Coefficients }\end{array}$ & & \\
Model & $\mathrm{B}$ & Std. Error & Beta & $\mathrm{t}$ & Sig. \\
\hline 1 (Constant) & 13.04 & 2.410 & & 5.411 & .000 \\
\hline Pelatihan (X) & .680 & .063 & .806 & 10.817 & .000 \\
\hline
\end{tabular}

Berdasarkan hasil pengujian pada tabel di atas, diperoleh persamaan regresi $\mathrm{Y}$ $=13,040+0,680 X$. Dari persamaan tersebut dijelaskan sebagai berikut:

1) Konstanta sebesar 13,040 diartikan jika pelatihan tidak ada, maka telah terdapat nilai kompetensi karyawan sebesar 13,040 point.

2) Koefisien regresi pelatihan sebesar 0,680 , angka ini positif artinya setiap ada peningkatan pelatihan sebesar 0,680 point maka kompetensi karyawan juga akan mengalami peningkatan sebesar 0,680 point.

\section{b. Analisis Koefisien Korelasi}

Analisis koefisien korelasi dimaksudkan untuk mengetahui tingkat kekuatan hubungan dari variabel independen terhadap variabel dependen. Adapun hasil pengujian sebagai berikut:

Tabel 3. Hasil Pengujian Koefisien Korelasi Pelatihan Terhadap Kompetensi Karyawan.

\section{Correlations $^{b}$}

\begin{tabular}{ll|r|r} 
& & $\begin{array}{c}\text { Pelatihan } \\
\text { (X1) }\end{array}$ & $\begin{array}{c}\text { Kompetensi } \\
\text { Karyawan (Y) }\end{array}$ \\
\hline Pelatihan (X) & $\begin{array}{l}\text { Pearson } \\
\text { Correlation }\end{array}$ & 1 & $.806^{* *}$ \\
\cline { 2 - 3 } & Sig. (2-tailed) & & .000 \\
\hline $\begin{array}{l}\text { Kompetensi Karyawan } \\
\text { (Y) }\end{array}$ & $\begin{array}{l}\text { Pearson } \\
\text { Correlation }\end{array}$ & $.806^{* *}$ & 1 \\
\cline { 2 - 3 } & Sig. (2-tailed) & .000 & \\
\hline
\end{tabular}

Berdasarkan hasil pengujian diperoleh nilai korelasi sebesar 0,806 artinya pelatihan memiliki hubungan yang kuat terhadap kompetensi karyawan.

\section{c. Analisis Koefisien Determinasi}

Analisis koefisien determinasi dimaksudkan untuk mengetahui besarnya persentase pengaruh dari variabel independen terhadap variabel dependen. Adapun hasil pengujian sebagai berikut: 
Tabel 4. Hasil Pengujian Koefisien Determinasi Pelatihan Terhadap Kompetensi Karyawan.

\begin{tabular}{|c|c|c|c|c|}
\hline \multicolumn{5}{|c|}{ Model Summary } \\
\hline Model & $\mathrm{R}$ & R Square & $\begin{array}{l}\text { Adjusted R } \\
\text { Square }\end{array}$ & $\begin{array}{l}\text { Std. Error of the } \\
\text { Estimate }\end{array}$ \\
\hline 1 & $.806^{\mathrm{a}}$ & .650 & .644 & 2.327 \\
\hline
\end{tabular}

Berdasarkan hasil pengujian diperoleh nilai determinasi sebesar 0,650 artinya pelatihan memiliki kontribusi pengaruh sebesar $65,0 \%$ terhadap kompetensi karyawan, sedangkan sisanya sebesar 35,0\% dipengaruhi oleh faktor lain yang tidak dilakukan penelitian.

\section{d. Uji Hipotesis}

Pengujian hipotesis dengan uji t digunakan untuk mengetahui hipotesis mana yang diterima. Rumusan hipotesis: Terdapat pengaruh yang signifikan pelatihan terhadap kompetensi karyawan.

Tabel 5. Hasil Uji Hipotesis Pelatihan Terhadap Kompetensi Karyawan.

\section{Coefficients $^{\mathrm{a}}$}

\begin{tabular}{|c|c|c|c|c|c|}
\hline \multirow[b]{2}{*}{ Model } & \multicolumn{2}{|c|}{$\begin{array}{l}\text { Unstandardized } \\
\text { Coefficients }\end{array}$} & \multirow{2}{*}{$\begin{array}{c}\text { Standardized } \\
\text { Coefficients } \\
\text { Beta }\end{array}$} & \multirow[b]{2}{*}{$\mathrm{t}$} & \multirow[b]{2}{*}{ Sig. } \\
\hline & B & Std. Error & & & \\
\hline 1 (Constant) & $\begin{array}{r}13.04 \\
0\end{array}$ & 2.410 & & 5.411 & .000 \\
\hline Pelatihan (X) & .680 & .063 & .806 & $\begin{array}{r}10.81 \\
7\end{array}$ & .000 \\
\hline
\end{tabular}

Berdasarkan hasil pengujian pada tabel di atas, diperoleh nilai t hitung $>\mathrm{t}$ tabel atau $(10,817>2,002)$, dengan demikian hipotesis yang diajukan bahwa terdapat pengaruh yang signifikan atara pelatihan terhadap kompetensi karyawan diterima.

\section{PEMBAHASAN HASIL PENELITIAN}

\section{Kondisi Jawaban Responden Variabel Pelatihan}

Berdasarkan jawaban responden, variabel pelatihan diperoleh ratting score sebesar 3,805 berada di rentang skala 3,40-4,19 dengan kriteria baik atau setuju.

\section{Kondisi Jawaban Responden Variabel Kompetensi Karyawan}


Berdasarkan jawaban responden, variabel kompetensi karyawan diperoleh ratting score sebesar 3,892 berada di rentang skala 3,40 - 4,19 dengan kriteria baik atau setuju.

\section{Pengaruh Pelatihan Terhadap Kompetensi Karyawan}

Pelatihan berpengaruh signifikan terhadap kompetensi karyawan dengan persamaan regresi $\mathrm{Y}=13,040+0,680 \mathrm{X}$, nilai korelasi sebesar 0,806 atau memiliki hubungan yang kuat dengan kontribusi pengaruh sebesar 65,0\%. Pengujian hipotesis diperoleh nilai $t$ hitung $>\mathrm{t}$ tabel atau $(10,817>2,002)$. Dengan demikian hipotesis yang diajukan bahwa terdapat berpengaruh signifikan antara pelatihan terhadap kompetensi karyawan diterima.

\section{KESIMPULAN DAN SARAN}

\section{Kesimpulan}

a. Variabel pelatihan diperoleh ratting score sebesar 3,805 berada di rentang skala 3,40 - 4,19 dengan kriteria baik atau setuju.

b. Variabel kompetensi karyawan diperoleh ratting score sebesar 3,892 berada di rentang skala 3,40 - 4,19 dengan kriteria baik atau setuju.

c. Pelatihan berpengaruh signifikan terhadap kompetensi karyawan dengan persamaan regresi $\mathrm{Y}=13,040+0,680 \mathrm{X}$, nilai korelasi sebesar 0,806 atau kuat dan kontribusi pengaruh sebesar $65,0 \%$ sedangkan sisanya sebesar 35,0\% dipengaruhi faktor lain. Uji hipotesis diperoleh nilai $\mathrm{t}$ hitung $>\mathrm{t}$ tabel atau $(10,817>2,002)$.

\section{Saran}

a. Kinerja dalam menjalankan fungsinya tidak berdiri sendiri, tetapi berhubungan dengan kemampuan dan motivasi kerja. Oleh karena itu perusahaan harus memikirkan cara yang diperlukan sumber daya manusia yang mempunyai kompetensi tinggi karena kompetensi akan dapat mendukung peningkatan prestasi kinerja pegawai

b. Kompetensi perusahaan dapat ditingkatkan dengan memberdayakan karyawan dengan menegakkan peraturan yang baik dan pemberian motivasi yang lebih inten lagi.

\section{DAFTAR PUSTAKA}

Abdullah, M (2014) Manajemen dan Evaluasi Kompetensi Karyawan, Yogyakarta: Penerbit Aswaja Pressindo.

Algifari. (2015). “Analisis Regresi untuk Bisnis dan Ekonomi”. Yogyakarta: BPFE.

Arikunto, Suharsimi (2014). “Prosedur Penelitian Suatu Pendekatan Praktek”. Jakarta: Rineka Cipta.

Bangun, Wilson. 2012. "Manajemen Sumber Daya Manusia”. Jakarta: Erlangga

Bejo Siswanto (2013) Manajemen Tenaga Kerja Rancangan dalam Pendayagunaan dan Pengembangan Unsur Tenaga Kerja”, Bandung: Sinar Baru.

Dessler, G. (2006.) Manajemen Sumber Daya Manusia (Jilid II). Jakarta: Indeks.

Edi Sutrisno (2016). Manajemen Sumber Daya Manusia. Jakarta: Prenadamedia Group. Edi Sutrisno (2016). Manajemen Sumber Daya Manusia. Jakarta: Prenadamedia Group. 
George Terry R \& Rue, Leslie W. Rue (2016) Dasar-Dasar Manajemen, Jakarta Bumi Aksara.

Gerry Dessler (2016) Human Resources Management, Prenticehall, London: International Inc.

Handoko (2016) Manajemen Personalia dan Sumberdaya Manusia. Yogyakarta: BPFE. Hasibuan, Malayu S.P. (2016). Manajemen Sumber Daya Manusia. Edisi Revisi. Jakarta: PT Bumi Aksara.

Imam Ghozali (2017). “Aplikasi Analisis Multivariate Dengan Program SPSS”. Edisi Kelima. Semarang: Badan Penerbit Undip.

Istijanto (2014) “Riset Sumber Daya Manusia”. Jakarta: PT. Gramedia Pustaka

Kosasih, et al. (2021). Pengaruh Lingkungan Kerja Dan Disiplin Kerja Terhadap Produktivitas Karyawan Pada PT. Graha Curah Niaga Di Tangerang. Jurnal Administrasi Bisnis (JUBIS). 1(1). 1-10

Kustini, E., et al. (2021). Pengaruh Keterampilan Kerja Dan Lingkungan Kerja Terhadap Kinerja Karyawan Pada PT. Garuda Daya Pratama Sejahtera (Garuda Indonesia Group). Jurnal Ilmiah PERKUSI, 1(3), 305-314.

Luthans Fred (2014) Organizational Behavior, Ney York: McGraw-Hill, New York.

Mangkunegara, Prabu Anwar. (2016). Evaluasi Kompetensi SDM. Cetakan ke tujuh, PT Refika Aditama: Bandung.

Nurjaya, N., et al. (2021). Pengaruh Kompetensi Sumber Daya Manusia Dan Kemampuan Pemanfaatan Teknologi Terhadap Kinerja Aparatur Desa Pada Kantor Kepala Desa Di Kabupaten Gunungkidul, Yogyakarta. JENIUS (Jurnal Ilmiah Manajemen Sumber Daya Manusia), 4(3), 332-346.

Robbins, P.S, \& Judge, A.T. (2003). Organizational Behavior. Jakarta: Salemba Empat.

Santoso, Singgih (2015). "Menguasai Statistik Multivariat”. Jakarta: PT Elex Media Komputindo.

Sedarmayanti (2016) Manajemen Sumber Daya Manusia, Reformasi Birokrasi dan Manajemen Karyawan Negeri Sipil, Cetakan Kelima, Bandung: PT Refika Aditama.

Sudjana (2014) “Metode Statistika”, Bandung: Tarsido.

Sugiyono (2017), "Metode Penelitian Administrasi : dilengkapi dengan Metode $R \&$ D". Bandung: Alfabeta.

Suwanto, S., et al. (2021). Pengaruh Motivasi Dan Pengalaman Kerja Terhadap Produktivitas Karyawan Pada Happy Restaurant Di Bandung. Jurnal Ekonomi Efektif, 3(4), 546-554.

Veithzal Rivai (2015) Manajemen Sumber Daya Manusia Untuk Perusahaan, Jakarta: Raja Grafindo Persada.

Wibowo (2015) Manajemen Kompetensi, Jakarta: PT. Raja Grafindo Persada. 